\title{
The new idea for modification of the surface area of silicate glass
}

\author{
Marcin Drajewicz ${ }^{1}$ Maciej Pytel ${ }^{1}\left[\right.$ Kamil Dychtoń $^{1}$
}

Received: 25 February 2019/Accepted: 28 September 2019/Published online: 18 October 2019

(C) The Author(s) 2019

\begin{abstract}
The paper presents a new and original method of modifying the surface layer of silicate glass by applying a coating produced from zirconium oxide-yttria-stabilized powder using the LPPS plasma method (low-pressure plasma spraying). This is a new approach and not found in both scientific literature and known technological solutions. The results of the work indicate that it is possible to produce the coatings of yttrium-stabilized zirconium oxide (YSZ) on the glass substrate. These coatings were made using the LPPS PS-PVD method and consist of fine YSZ crystals with spheroidal morphology. This gradient coating (FGM) has a thickness controlled from LPPS of several dozen to hundreds of nanometers. It effectively modifies the properties of the glass by introducing favorable stresses on the surface and therefore increases its hardness and tensile strength. At the same time, thermal properties of the glass were determined, which allowed to determine the temperature of heating the glass substrate necessary for the proper implementation of the oxide coating production process on this substrate by the LPPS method. The glass parameters achieved in the work are very promising and comparable with the characteristics of the best glasses currently used in optoelectronics, especially in the displays of mobile phones and solar cells.
\end{abstract}

Keywords Thermal analysis · Silicate glass · LPPS PS-PVD method · Yttria-stabilized zirconia coating · SEM microstructural examinations

\section{Introduction}

Mechanical properties of glasses determine their development and use. However, they often limit their performance. Particular properties are concerned, that depend on phase composition and structure of the surface coating. Hence, improvement in glass properties, especially durability, is currently achieved by modification of its surface or constitution of a new coating on the glass substrate, among others, by forming a thin oxide coating by surface engineering methods. Analysis of literature data indicates the ability to increase glass strength properties by forming of polycrystalline tetragonal $t-\mathrm{ZrO}_{2}$ coating on its surface $[1,2]$. Zirconia can occur in several polymorphic forms, which are characterized by a monoclinic, regular and

Marcin Drajewicz

drajewic@prz.edu.pl

1 Department of Material Science, The Faculty of Mechanical Engineering and Aeronautics, Rzeszów University of Technology, Powstańców Warszawy 8, 35-959 Rzeszow, Poland tetragonal structure, which affects its various mechanical or thermal properties. In addition, $\mathrm{ZrO}_{2}$ oxide in the tetragonal structure ( $t$ phase) can be stabilized with other oxides (e.g., $\mathrm{MgO}, \mathrm{CaO}, \mathrm{Ce}_{2} \mathrm{O}_{3}$ and $\mathrm{Y}_{2} \mathrm{O}_{3}$ ) up to the metastable phase $t^{\prime}$, which increases its useful properties, and then its thermal stability increases significantly. Stabilization of zirconia with yttrium oxide gives the best results, because it is the least sensitive to the effects of temperature changes and the accompanying unfavorable phase transitions. Data analysis shows that the $\mathrm{ZrO}_{2}$ coating can be prepared on the glass surface by various methods including sol-gel and chemical vapor deposition (CVD) [2-6]. At the same time, recent years brought rapid development of methods for thermal spraying. One of them is physical vapor deposition with plasma evaporation under reduced pressure (50-200 Pa)—LPPS (low-pressure plasma spraying). In the various researches, new conditions were developed for coatings application both on metallic and non-metallic substrates. For example, increasing length of the plasma beam and use of powder of micro- and nanometric size and their proper morphology allow manufacturing of homogeneous coating of uniform thickness 
over a large area. Therefore, the assumption was adopted that application of stabilized $\mathrm{ZrO}_{2} \times n \mathrm{Y}_{2} \mathrm{O}_{3}$ oxide of micro- and nanometric particle size in the process of physical vapor deposition under reduced pressure and elevated temperature allows formation of stable and strengthened surface coating on the glass substrate. It was assumed that the produced coating will provide enhanced effect of strengthening of soda-calcium-silicate glass [7-11]. At the same time, an attempt was made to develop comprehensive selection criteria for both coating materials and process conditions for plasma spraying under reduced pressure to produce a strengthened and uniform coating that consisted of $\mathrm{ZrO}_{2} \times n \mathrm{Y}_{2} \mathrm{O}_{3}$ oxide in the industrial soda-calcium-silicate glass substrate. The research described thermal properties [12-15].

\section{Experimental}

The work described selection of criteria for proper execution of the $\mathrm{ZrO}_{2}$ manufacturing process on glass, which meets established physical, chemical and functional assumptions. It was found that proper selection of process conditions is crucial for plasma spraying of uniform oxide coating of predetermined thickness with projected properties. Conditions for the process, as pressure in the working chamber-150 $\mathrm{Pa}$ and the distance between the plasma torch and the substrate- $1300 \mathrm{~mm}$, were established in the research methodology.

The test samples were made of commercial soda-calcium-silicate glass. Prior to the PS-PVD process, the samples were cleaned in isopropyl alcohol in an ultrasonic cleaner for $15 \mathrm{~min}$. The glass samples were then placed in a pre-chamber in which a vacuum was created to a value of $150 \mathrm{~Pa}$. After reaching the required pressure $(150 \mathrm{~Pa})$ in both chambers, the samples were transported from the prechamber to the working chamber, in which the process of sample pre-heating was carried out by the plasma beam which was formed with current of $1200 \mathrm{~A}$ and argon flow of $160 \mathrm{dm}^{3} \mathrm{~min}^{-1}$ at $150 \mathrm{~Pa}$. For ensuring stabilization of forming coating, the torch performed swinging movement with $1 \mathrm{~Hz}$ frequency, and a substrate was rotating at $10 \mathrm{rpm}$. During the deposition, commercial Metco 6700 ceramic powder $\mathrm{ZrO}_{2} \times(7.5$ mass $\%) \quad \mathrm{Y}_{2} \mathrm{O}_{3}$ was let into the helium-argon plasma beam. It has been determined that for obtaining stable plasma, the minimum flow rate of helium should be on the level of $60 \mathrm{dm}^{3} \mathrm{~min}^{-1}$ and of argon on the level of $35 \mathrm{dm}^{3} \mathrm{~min}^{-1}$, while the electrical current should be on the level of $1600 \mathrm{~A}$. Total evaporation of powder was achieved by its flow rate of $1 \mathrm{dm}^{3} \mathrm{~min}^{-1}$.

The article specifies the thermal conductivity, thermal diffusivity and specific heat of both glass as well as the deposited coatings. They were the main criteria for selection of the conditions for the production of coatings on the glass and are necessary for the development of physical models and numerical simulation of thermal processes.

Thermal diffusivity of glass was determined by pulsed laser method with unidirectional heat transfer of the laser beam. The laser radiation energy of the laser beam is absorbed on the surface of the sample substrate and violates the thermal equilibrium state.

The resulting non-equilibrium state stabilizes after a certain time and is then a surface source of heat. At the same time, a temperature gradient is created on the thickness of the sample-glass. This gradient causes the heat to flow toward the lower-temperature surface. The InSb infrared sensor was used to measure the value of this temperature as a function of time. At the same time, the adopted adiabatic measurement conditions also allow determining the thermal diffusivity of the tested material based on the dependence [16]:

$a=0.1388 \cdot \frac{d^{2}}{t_{0.5}}\left[\mathrm{~mm}^{2} \mathrm{~s}^{-1}\right]$

The thermal diffusivity of the glass was determined using the Netzsch LFA 427 device for the adopted measurement conditions (Table 1).

The specific heat of the materials used in the tests was determined by the $C \mathrm{p}$-DSC differential scanning calorimetry method. The difference in heat fluxes between the tested glass samples and the reference material was determined. In the measurements of specific heat of glass, the DSC curve of the sapphire was used as a comparative. The specific heat value of these materials was determined in accordance with ASTM E1269 and DIN 51007 for the adopted measurement conditions (Table 2). The measurements were carried out using the Netzsch Saturn F3 Jupiter differential calorimeter.

The values of thermal coefficient of linear expansion of the tested materials in the temperature range from 25 to $800{ }^{\circ} \mathrm{C}$ were determined in dilatometric examinations carried out in helium atmosphere using the DIL 402

Table 1 Conditions for measuring the thermal diffusivity of glass

\begin{tabular}{ll}
\hline Conditions of measurement & Glass \\
\hline Reference temperature $/{ }^{\circ} \mathrm{C}$ & 25 \\
Conductive coating & Graphit 33 \\
Sample thickness $/ \mathrm{mm}$ & 2.11 \\
Sample diameter $/ \mathrm{mm}$ & 12.54 \\
Infrared sensor & $\mathrm{InSb}$ \\
Protective gas & $\mathrm{Ar}$ \\
Flow rate Ar $/ \mathrm{cm}^{3} \mathrm{~min}^{-1}$ & 100 \\
Heating rate $/{ }^{\circ} \mathrm{C} \mathrm{min}^{-1}$ & 5 \\
\hline
\end{tabular}


Table 2 Conditions for measuring the specific heat of glass

\begin{tabular}{ll}
\hline Conditions of measurement & Glass \\
\hline Reference temperature, $/{ }^{\circ} \mathrm{C}$ & 25 \\
Sapphire weight $/ \mathrm{mg}$ & 20 \\
Sample weight $/ \mathrm{mg}$ & 22 \\
Protective gas & $\mathrm{Ar}$ \\
Flow rate Ar $/ \mathrm{cm}^{3} \mathrm{~min}^{-1}$ & 50 \\
Heating rate $/{ }^{\circ} \mathrm{C} \mathrm{min}^{-1}$ & 10
\end{tabular}

dilatometer from the Netzsch company. Round samples with diameter of $6 \mathrm{~mm}$ and length of $25 \mathrm{~mm}$ were used, and their heating and cooling rate was $5 \mathrm{~K} \mathrm{~min}^{-1}$.

Obtained results of dilatometer tests were at the same time the basis for determining the density of glass. It was assumed that soda-calcium-silicate glass is isotropicthere are no differences in the thermal coefficient of linear expansion depending on the direction of measurement. The density of the glass at $25{ }^{\circ} \mathrm{C}$ was also determined using the AccuPyc 1330 pycnometer from Micromeritics. The helium atmosphere was used. Obtained results of the thermal diffusivity, specific heat and glass density tests were the basis for determining its thermal conductivity in accordance with equation [16]:

$$
\lambda(T)=a(T) \cdot c_{\mathrm{p}}(T) \cdot \rho(T),\left[\mathrm{W} \mathrm{m}^{-1} \mathrm{~K}^{-1}\right]
$$

Microstructural examination of the YSZ-coated glass samples was carried out using scanning electron microscope Hitachi S3400N equipped with the Thermo Scientific $^{\mathrm{TM}}$ UltraDry EDS Detector and Thermo Scientific ${ }^{\mathrm{TM}}$ NORAN $^{\mathrm{TM}}$ System 7 for chemical composition microanalysis by use of an energy-dispersive X-ray spectroscopy (EDX) technique. Microstructural observations were performed to evaluate the changes in the glass surface morphology after the LPPS process of $\mathrm{ZrO}_{2} \cdot \mathrm{Y}_{2} \mathrm{O}_{3}$ coating deposition.

\section{Results}

Verification of adopted hypothesis and setting the correct thermal spraying conditions led to the stabilization of the process parameters. Thermal properties were measured: specific heat, thermal diffusivity and thermal conductivity. In the study, glass density was also determined as a function of temperature in the range 25 to $700{ }^{\circ} \mathrm{C}$. It was found that relative change in the density of glass is approx. $1.6 \%$ for temperature range from 25 to $700{ }^{\circ} \mathrm{C}$.

Coefficient of linear thermal expansion and thermal expansion of analyzed glasses types were determined for heating rate of $5 \mathrm{~K} \mathrm{~min}^{-1}$ from temperature varying in the range of 25 to $700{ }^{\circ} \mathrm{C}$ (Figs. 1, 2). It has been found that the values of linear thermal expansion coefficient for analyzed glasses are different: for basic glass at $25^{\circ} \mathrm{C}$ it is approximately $8.4 \times 10^{-6} \mathrm{~K}^{-1}$ and increases to $9.62 \times 10^{-6} \mathrm{~K}^{-1}$ at $550{ }^{\circ} \mathrm{C}$, whereas for YSZ-coated glass at $25^{\circ} \mathrm{C}$ it is approximately $5.14 \times 10^{-6} \mathrm{~K}^{-1}$ and increases to $6.07 \times 10^{-6} \mathrm{~K}^{-1}$ at $585{ }^{\circ} \mathrm{C}$ (Fig. 1). For each of the analyzed samples, both basic glass as well as coated glass above the temperature of transition $T_{\mathrm{g}}$, the value of linear thermal expansion coefficient increases. The softening point is, respectively, $10.5 \times 10^{-6} \mathrm{~K}^{-1}$ at $585^{\circ} \mathrm{C}$ for basic glass and $7.45 \times 10^{-6} \mathrm{~K}^{-1}$ at $658{ }^{\circ} \mathrm{C}$ for coated glass.

The values of thermal expansion show that differences in elongation during heating between basic glass and glass with YSZ coating occur (Fig. 2). Moreover, temperatures of transition $T_{\mathrm{g}}$ and softening $T_{\mathrm{d}}$ were determined for tested glasses. For a glass without coating, the $T_{\mathrm{g}}$ and $T_{\mathrm{d}}$ temperatures are, respectively, 549 and $585^{\circ} \mathrm{C}$. For a glass with YSZ coating, the $T_{\mathrm{g}}$ and $T_{\mathrm{d}}$ temperatures are, respectively, 585 and $658^{\circ} \mathrm{C}$. Specific heat values were determined for basic glass and glass with YSZ coating on one side in room temperature (Fig. 3). For basic glass it is approximately $0.8 \pm 0.04 \mathrm{~J} \mathrm{~g}^{-1} \mathrm{~K}^{-1}$ while for YSZ coated glass it is $0.7 \pm 0.04 \mathrm{~J} \mathrm{~g}^{-1} \mathrm{~K}^{-1}$. These values increase with the temperature. At the 500 and $600{ }^{\circ} \mathrm{C}$, it is approximately 1.05 and $1.3 \pm 0.04 \mathrm{~J} \mathrm{~g}^{-1} \mathrm{~K}^{-1}$ for basic glass and approximately $0.96 \pm 0.04 \mathrm{~J} \mathrm{~g}^{-1} \mathrm{~K}^{-1}$ and $1.2 \pm 0.04 \mathrm{~J} \mathrm{~g}^{-1} \mathrm{~K}^{-1}$ for YSZ coated glass (Fig. 3).

Thermal diffusivity and conductivity of glass also take similar values at room temperature. It is approximately $0.445 \pm 0.01 \mathrm{~mm}^{2} \mathrm{~s}^{-1}$ (Fig. 4) and $1.07 \pm 0.01 \mathrm{~W} \mathrm{~m}^{-1} \mathrm{~K}^{-1}$ (Fig. 5) for basic glass and approximately $0.420 \pm$ $0.01 \mathrm{~mm}^{2} \mathrm{~s}^{-1} \quad$ (Fig. 4) and $0.949 \pm 0.01 \mathrm{~W} \mathrm{~m}^{-1} \mathrm{~K}^{-1}$ (Fig. 5) for glass with YSZ coating on one side. Thermal

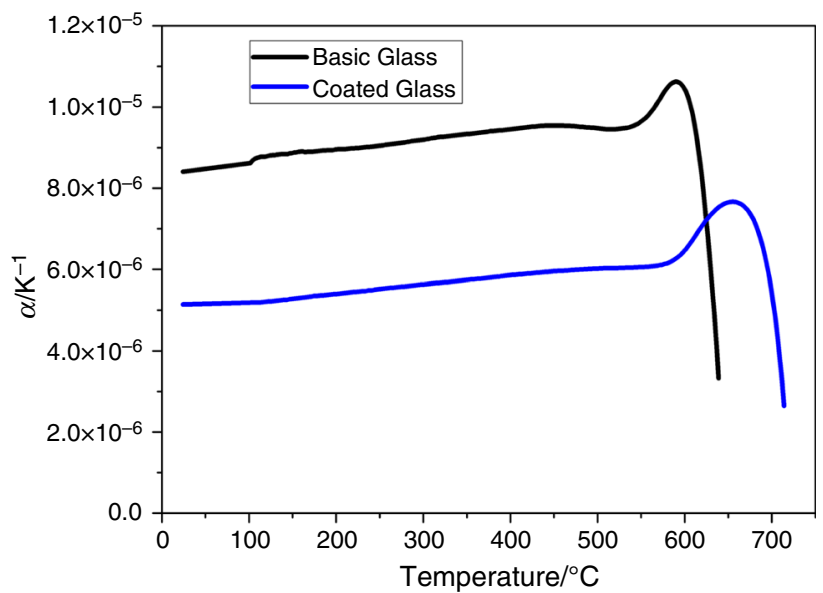

Fig. 1 Coefficient of linear thermal expansion in the temperature range 25 to $700{ }^{\circ} \mathrm{C}$ 


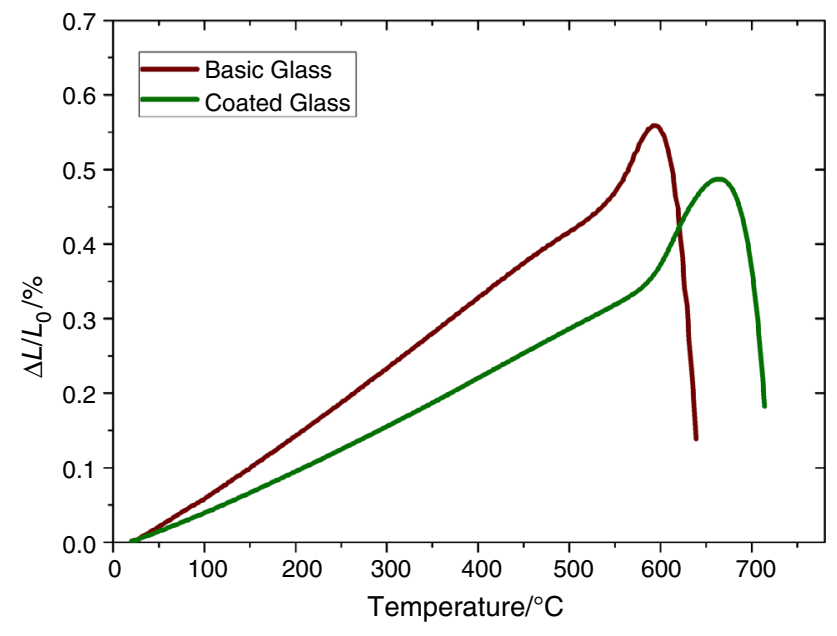

Fig. 2 Thermal expansion in the temperature range 25 to $700{ }^{\circ} \mathrm{C}$

diffusivity decreases with increase in temperature in the range from 200 to $500{ }^{\circ} \mathrm{C}$ and takes a value of approximately $0.445 \pm 0.01 \mathrm{~mm}^{2} \mathrm{~s}^{-1}$ for basic glass and approximately $0.440 \pm 0.01 \mathrm{~mm}^{2} \mathrm{~s}^{-1}$ (Fig. 4) for glass with YSZ coating on one side. After glass transition, values of thermal diffusivity for both glasses are approximately $0.370 \pm 0.01 \mathrm{~mm}^{2} \mathrm{~s}^{-1}$; for $700{ }^{\circ} \mathrm{C}$, it is $0.282 \pm 0.01 \mathrm{~mm}^{2} \mathrm{~s}^{-1}$ (Fig. 4). However, thermal conductivity increases after glass transition for both glasses, respectively, to $1.25 \pm 0.01$ for basic uncoated glass and $1.01 \pm 0.01 \mathrm{~W} \mathrm{~m}^{-1} \mathrm{~K}^{-1}$ for YSZ coated glass (Fig. 5).

Obtained results show changes in thermal properties of investigated glass samples according to increase in temperature. The change in thermal diffusivity and specific heat for both glasses change gradually to the transformation and softening temperature. Analysis of thermal properties allowed determining the glass heating temperature $\left(720^{\circ} \mathrm{C}\right)$ necessary for proper implementation of oxide

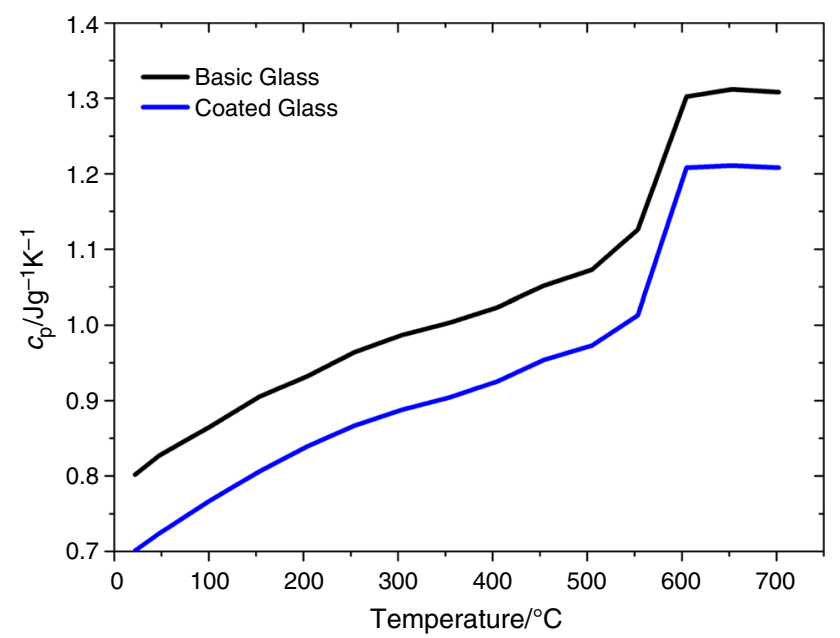

Fig. 3 Specific heat in the temperature range 25 to $700{ }^{\circ} \mathrm{C}$

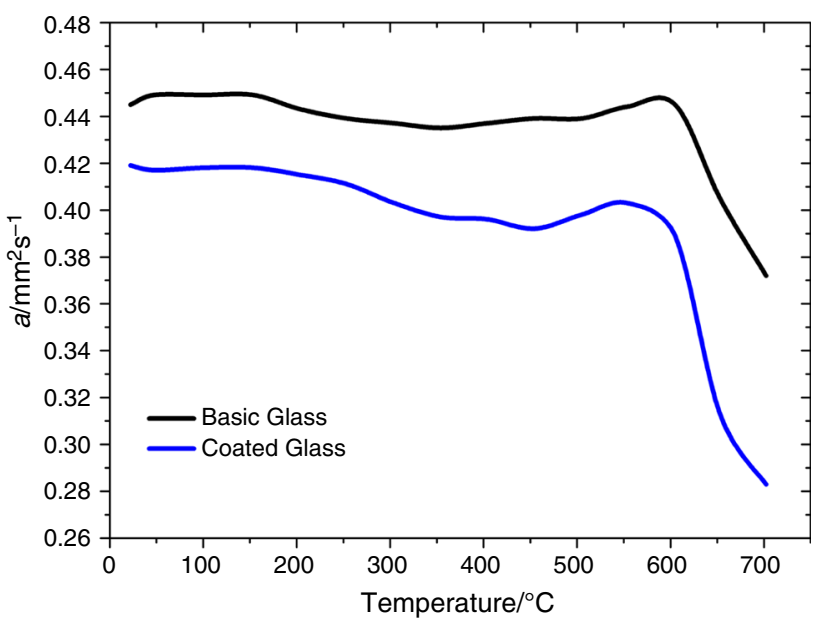

Fig. 4 Thermal diffusivity in the temperature range 25 to $700{ }^{\circ} \mathrm{C}$

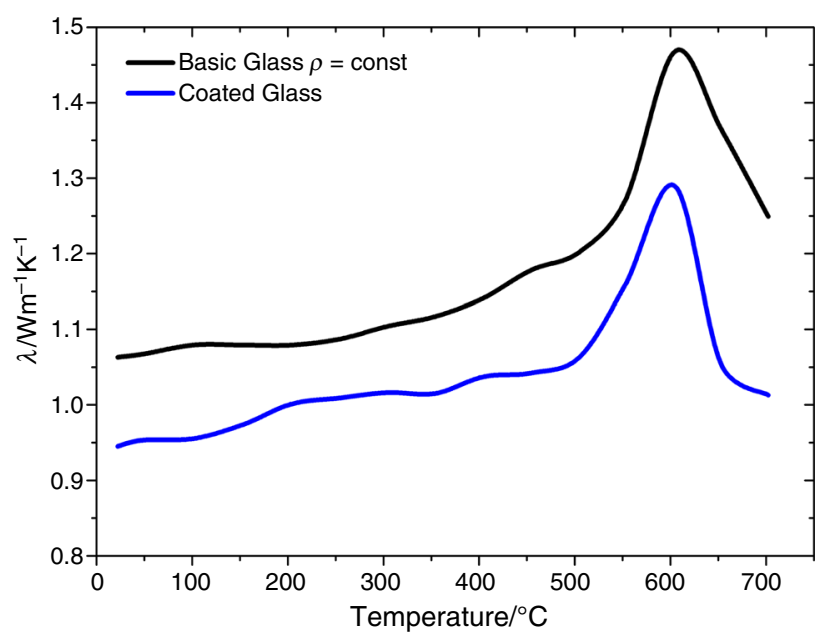

Fig. 5 Thermal conductivity in the temperature range 25 to $700{ }^{\circ} \mathrm{C}$

forming process by plasma spraying under reduced pressure.

The results of SEM microscopic investigations of YSZ coatings produced by the LPPS PS-PVD method on a soda-calcium-silicate glass substrate indicate an even growth of these coatings and their compact structure. Few areas of the YSZ coating are visible with defects in the form of microcracks, voids, or unmelted YSZ powder particles. In Fig. 6c-d, both micro-areas of produced YSZ coating and few micro-areas with cavities and also microcracks are visible. During the microscopic (SEM) examinations of these coatings, it was found that the mean value of their thickness is of about $1.25 \mu \mathrm{m}$ (Fig. 6a). It was also observed that the YSZ coating consists of very small individual columns, similar to the thick YSZ columnar coating formed in the PS-PVD process for commercial Thermal Barrier Coatings producing for The Aerospace Industry. With this difference, the growth rate 

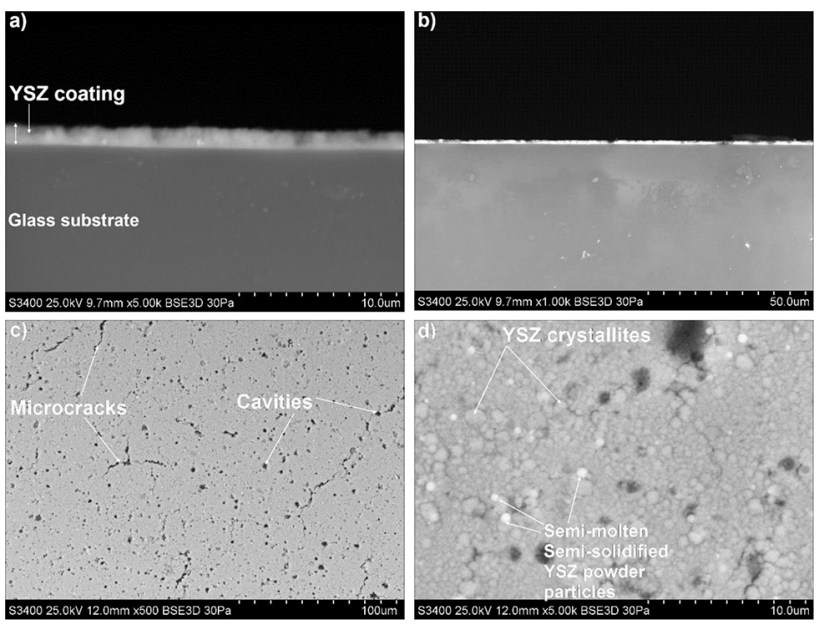

Fig. 6 Microstructure of yttria-stabilized zirconia $\left(\mathrm{ZrO}_{2} \cdot \mathrm{Y}_{2} \mathrm{O}_{3}\right)$ coating deposited from Metco 6700 ceramic powder during LPPS process on the substrate of soda-calcium-silicate glass: a at the cross section of YSZ coating-larger magnification and $\mathbf{b}$ lower magnification; $\mathbf{c}$, d morphology of the YSZ coating surface-lower and higher magnifications

of each coating is different for each of these processes; their densities are completely different as well as their intercolumnar porosity is different [17-19]. The scanning electron micrograph taken in backscattered electrons mode (SEM-BSE) shown in Fig. 6c-d reveals the spherical morphology of the tops of individual crystallites from which the coating is built up. At the same time, there are few single microcracks that do not form a microcracks network. There are also very few individual YSZ particles that have not been solidified, but have probably been semimelted and also semi-solidified and have not been able to evaporate into the vapor phase. These particles were characterized by spherical morphology and a diameter of about $200 \mathrm{~nm}$ to about $670 \mathrm{~nm}$; their average diameter was about $450-500 \mathrm{~nm}$. It was also found that irregularly distributed single cavities are present, which occur most often at the interface of several microcracks. It should be emphasized that the coating adheres well to the glass surface, and there are no gaps between the coating and the glass surface. No delamination and visible coating imperfections were observed. The coating evenly covered the entire surface of the glass onto which it was applied.

\section{Conclusions}

On the basis of the results obtained from the performed research, it was found that it is possible to produce YSZ coating on SLS (soda-calcium-silicate/soda-lime-silicate) glass during LPPS PS-PVD process in strictly industrial conditions. At the same time, the required thermal properties of the glass are maintained.
At the same time, based on the analysis of thermal properties, conditions for the production of such coatings on the SLS glass substrate were developed, and also process temperature and the effect of the YSZ coating produced on the glass substrate on the thermal properties of this material combination were examined. It has been found that the presence of the YSZ coating on the glass substrate reduces its thermal diffusivity, thermal conductivity and specific heat, while the thermal expansion decreases, including the value of the thermal linear expansion coefficient.

The results achieved at work are very promising and comparable with the characteristics of the best glass currently used in optoelectronics, especially in the displays of cell phones and solar cells. At the same time, the method seems cheaper and more effective for use on an industrial scale. It is also very developmental. At the same time, research results obtained in previous works indicate that formation of a new surface coating consisting of $\mathrm{ZrO}_{2-}$ $\mathrm{Y}_{2} \mathrm{O}_{3}$ crystallites effectively modifies the properties of the glass by introducing favorable stresses on the surface and therefore increases its hardness and tensile strength $[1,2,7,8]$.

Open Access This article is distributed under the terms of the Creative Commons Attribution 4.0 International License (http://creative commons.org/licenses/by/4.0/), which permits unrestricted use, distribution, and reproduction in any medium, provided you give appropriate credit to the original author(s) and the source, provide a link to the Creative Commons license, and indicate if changes were made.

\section{References}

1. Drajewicz M. Modification of the surface layer of soda-limesilicate glass_-physical, optical and mechanical properties. 2016; Rzeszów, Poland.

2. U.S. Patent. US20150132563A1. Scratch-resistant liquid based coatings for glass.

3. Poungkaew T, Jaimasith M, Leowkijsiri P, Thiemsorn W. Industrial soda-lime-silica sheet glass hardened by Zirconia-reinforced inorganic coating. TNI J Eng Technol. 2014;2(1):6-10.

4. Yu JJ, Boyd IW. $\mathrm{ZrO}_{2}$ films deposited by photo-CVD at low temperatures. Appl Phys A. 2002;75(4):489-91.

5. Bastianini A, Battiston G, Gerbasi R, Porchia M, Daolio S. Chemical vapor deposition of $\mathrm{ZrO}_{2}$ thin films using $\mathrm{Zr}\left(\mathrm{NEt}_{2}\right) 4$ as precursor. J Phys IV Colloq. 1995;05(C5):C5-525-31.

6. Bajraktarova-Valjakova E, Korunoska-Stevkovska V, Kapusevska B, Gigovski N, Cvetanka Bajraktarova-Misevska C, Grozdanov A. Contemporary dental ceramic materials, a review: chemical composition, physical and mechanical properties, indications for use. Open Access Maced J Med Sci. 2018;6(9):1742-55.

7. Dychtón K, Drajewicz M, Pytel M, Rokicki P, Nowotnik A. Yttria-stabilized zirconia alumina composite sintering temperature effect on thermal diffusivity. J Therm Anal Calorim. 2016;126:1-7.

8. Sitarz M, Drajewicz M, Jadach R, Długoń E, Leśniak M, Reben M, Wajda A, Gawęda A, Burtan-Gwizdała B. Optical and 
mechanical characterization of zirconium based sol-gel coatings on glass. Arch Metall Mater. 2016;61(4):1747-52.

9. Drajewicz M, Pytel M, Rokicki P, Góral M. The surface morphology and optical properties of refined glasses with inorganic nano-molecules. High Temp Mater Process (London). 2015;34(3):257-61.

10. Drajewicz M, Góral M, Pytel M, Sieniawski J. Thermophysical properties of selected powders for thermal barrier coatings. J Achiev Mater Manuf Eng. 2012;55(2):902-6.

11. Góral M, Kotowski S, Dychtoń K, Drajewicz M, Kubaszek T. Influence of low pressure plasma spraying parameters on MCrAlY bond coat and its microstructure. Key Eng Mater. 2014;592-593:421-4.

12. Gaal PS, Thermitus MA, Stroe DE. Thermal conductivity measurements using the flash method. J Therm Anal Calorim. 2004;78:185-9.

13. Manuelian M, Campbell R. Thermal diffusivity, specific heat, and thermal conductivity measurment using NETZSCH LFA 447 NanoflashTM. Netzsch Instrum. 2008;1-8.

14. Parker WJ, Jenkins RJ, Butter CP, Abbot GL. Flash method of determining thermal diffusivity, heat capacity and thermal conductivity. J Appl Phys. 1961;32:1679-84.
15. Shinzato K, Baba T. A laser flash apparatus for thermal diffusivity and specific heat capacity measurements. J Therm Anal Calorim. 2001;64:413-22.

16. Sestak J, Simon P. Thermal analysis of micro, nano and noncrystalline materials: transformation, crystallization, kinetics and thermodynamics. New York: Springer; 2013.

17. Zhang Baopeng, Wei Liangliang, Guo Hongbo, Huibin $\mathrm{Xu}$. Microstructures and deposition mechanisms of quasi-columnar structured yttria-stabilized zirconia coatings by plasma spray physical vapor deposition. Ceram Int. 2017;43(15):2920-9.

18. Von Niessen K, Gindrat M, Refke A. Vapor phase deposition using plasma spray-PVD. J Therm Spray Technol. 2010;19(1-2):502-9.

19. Góral M, Kotowski S, Nowotnik A, Pytel M, Drajewicz M, Sieniawski J. PS-PVD deposition of thermal barier coating. Surf Coat Technol. 2013;237:51-5.

Publisher's Note Springer Nature remains neutral with regard to jurisdictional claims in published maps and institutional affiliations. 